\title{
PENINGKATAN PRESTASI BAHASA ARAB SISWA MELALUI MEDIA TEKA TEKI SILANG DI MA MA'ARIF 07 BANJARWATI PACIRAN
}

\author{
Siti Noer Fadillah 1), Fahrur Rosikh2) \\ Institut Pesantren Sunan Drajat Lamongan, Indonesia $a^{1,2}$ \\ Email: sitinurf027@gmail.com¹, frrosikh@gmail.com² \\ Dikirim: 28 Desember 2020 | Direvisi: 18 Januari 2021 | Dipublikeasikan: 31 Januari 2021
}

\begin{abstract}
Abstraksi: Pembelajaran bahasa Arab di MA Ma'arif 7 Banjarwati Paciran Lamongan masih belum terlepas dari permasalahan. Diantara permasalahan tersebut adalah rendahnya prestasi belajar bahasa Arab pada aspek menulis dan merangkai kata/kalimat dan rendahnya motivasi belajar. Penelitian ini bertujuan untuk meningkatkan prestasi belajar bahasa Arab pada aspek imla'. Jenis penelitian yang digunakan adalah penelitian tindakan kelas, subjek penelitian siswa kelas XI-K IPS MA Ma'arif 7 Banjarwati Paciran Lamongan tahun pelajaran 2020/2021. Instrumen penelitian menggunakan observasi, wawancara dan tes. Sedangkan analisis data menggunakan. Hasil penelitian ini menunjukan bahwa media Teka Teki Silang (TTS) dapat meningkatkan prestasi belajar imla' bahasa Arab siwa kelas XI-K IPS MA Ma'arif 7 Banjarwati. Hal ini dapat diketahui dari ketuntasan belajar pada siklus I diperoleh rata-rat nilai $67 \%$, dan pada siklus II diperoleh rata-rata nilai 73\% dan pada siklus III diperoleh rata-rat nilai 93\%.

Kata kunci: Prestasi; bahasa Arab; media teka teki silang.
\end{abstract}

\section{Pendahuluan}

Pembelajaran adalah upaya yang dilakukan oleh guru dalam menciptakan kegiatan belajar materi tertentu yang kondusif untuk mencapai tujuan. Sedangkan pembelajaran bahasa asing adalah kegiatan mengajar yang dilakukan secara maksimal oleh seorang guru agar anak didik yang ia ajari bahasa asing tertentu melakukan kegiatan belajar dengan baik sehingga kondusif untuk mencapai tujuan belajar bahasa asing. ${ }^{1}$

Sebagaimana kita ketahui, tujuan utama dari pembelajaran bahasa Arab adalah menggali dan mengembangkan kemampuan peserta didik dalam menggunakan bahasa, baik secara aktif (lisan/syafâwi) ataupun pasif (tulis/kitābî). Dengan pembelajaran bahasa secara terus menerus dapat diperoleh keterampilan berbahasa yang umumnya masih dikenal dengan empat macam keterampilan berbahasa, yakni keterampilan menyimak (mahärah istimāa), keterampilan berbicara (mahärab kaläm), keterampilan membaca (mahärah qirāah) dan keterampilan menulis (mahärah kitāabab). ${ }^{2}$

Pembelajaran bahasa Arab di Madrasah Aliyah tempat peneliti melakukan penelitian ini mempunyai tujuan agar para siswa berkembang dalam hal kemampuan mendengarkan, berbicara, membaca, dan menulis secara baik. Hal yang diinginkan guru adalah siswa dapat menghayati dan menghargai karya sastra, dapat berbicara secara sederhana, dapat menafsirkan isi berbagai bentuk teks dan dapat menulis kreatif. ${ }^{3}$

Dari hasil studi pendahuluan yang dilakukan oleh peneliti dengan melakukan wawancara dengan guru bahasa Arab Madrasah Aliyah Ma'arif 7 Banjarwati Paciran Lamongan yang dilakukan pada tanggal 19 Oktober 2019, dapat diketahui bahwa guru sudah menerapkan beberapa metode

\footnotetext{
1 Agus Suprijono, Cooperative Learning (Surabaya: Pustaka Pelajar, 2009), 13.

2 Ulin Nuha, Metodologi Super Efektif Pembelajaran Bahasa Arab (Yogyakarta: DIVA Press, 2012), 83.

${ }^{3}$ Ulin Nuha, Ragam Metodologi \& Media Pembelajaran Bahasa Arab (Yogyakarta: DIVA Press, 2016), 250.
} 
pembelajaran pada saat kegiatan balajar mengajar antara lain metode ceramah, diskusi dan penugasan. Akan tetapi, didalam proses pembelajaran ditemukan berbagai permasalahan diantaranya yaitu keterampilan imla' bahasa Arab siswa yang masih rendah terlihat pada banyaknya siswa yang tidak mau menulis saat proses pembelajaran berlangsung ataupun saat memberikan tugas kepada siswa untuk dikerjakan dirumah. ${ }^{4}$

Berdasarkan informasi yang didapatkan dari beberapa siswa, problematika yang dihadapi oleh mereka adalah mereka belum bisa menulis Arab dengan baik dan tulisannya kurang bagus karena tidak terbiasa dengan menulis dengan menggunakan bahasa Arab. Kemudian mereka juga kesulitan dalam menulis bahasa Arab dengan harakat yang benar karena mereka tidak mengetahui kaidah tulisan bahasa Arab, dan kesulitan siswa dalam merangkai beberapa kalimat dalam kaidah yang benar disebabkan keraguan siswa dengan susunan kalimat yang ditulis, apakah sudah benar ataukah salah. ${ }^{5}$

Imla' merupakan salah satu pembagian dari keterampilan menulis (mahärah kitāabah) yang mana harus dipelajari dengan sungguh-sungguh karena imla' adalah awal dari penulisan huruf bahasa Arab. Menurut Acep Hermawan dalam buku Metodologi Pembelajaran Bahasa Arab, imla' (al-imlā) adalah kategori menulis yang menekankan rupa/postur huruf sesuai posisinya yang benar dalam membentuk kata-kata dan kalimat. Perbedaan dengan kaligrafi (al-khat) adalah tidak hanya menekankan rupa/postur huruf dalam membentuk kata-kata atau kalimat, tetapi juga menyentuh aspek-aspek estetika (al-Jamā̄). Sedangkan mengarang (al-insya $\bar{a}$ ) adalah kategori menulis yang berorientasi kepada pengekspresian pokok pikiran berupa ide, pesan, perasaan, dan sebagainya ke dalam dalam bentuk tulisan, bukan visualisasi bentuk atau rupa huruf, kata, atau kalimat saja. Dengan kata lain menulis karangan tidak hanya mendeskripsikan kata-kata atau kalimat ke dalam tulisan secara struktural, melainkan juga bagaimana ide atau pikiran penulis tercurah secara sistematis untuk meyakinkan pembaca. ${ }^{6}$

Permasalahan berikutnya yang peneliti temukan di Madrasah Aliyah Ma'arif 7 Banjarwati ini adalah minimnya penggunaan media pembelajaran yang dapat menunjang pembelajaran bahasa Arab siswa dikelas. Media yang biasa digunakan oleh guru hanyalah buku paket yang dianggap kurang menarik dan membosankan, yang akhirnya berakibat pada asumsi siswa bahwa pelajaran bahasa Arab sama dengan pelajaran lainnya dan bahasa Arab merupakan bahasa yang sulit untuk dipahami. Tidak hanya itu, permasalahan yang terjadi dikelas XI-K IPSini adalah aktifitas siswa yang pasif dalam berkomunikasi dengan menggunakan bahasa Arab. Mereka cenderung diam mendengarkan guru dan tidak ada respon ketika guru bertanya ataupun memberikan kesempatan siswa untuk berbicara/bertanya. Alhasil, nilai yang mereka peroleh pada saat ujian semester masih dibawah KKM (Kriteria Ketuntasan Minimal) yang ditentukan oleh madrasah, yang mana dari 23 siswa yang terdapat di kelas hanya 3 siswa yang lolos (melebihi KKM). ${ }^{7}$

Permasalahan-permasalahan yang ditemukan di madrasah tersebut bisa dipecahkan jika pembelajaran bahasa Arab berjalan efektif diantaranya dengan memberi kesempatan pada siswa untuk melatih keterampilan imla' bahasa Arab siswa, memperbanyak latihan supaya siswa menjadi aktif bukan hanya guru saja dan menggunakan media pembelajaran yang bervariasi.

\footnotetext{
${ }^{4}$ Hasil wawancara dengan guru bahasa Arab MA Ma’arif 7 Banjarwati Paciran Lamongan pada tanggal 19 Oktober 2019.

${ }^{5}$ Hasil wawancara dengan beberapa siswa kelas XI-K IPSMA Ma’arif 7 Banjarwati Paciran Lamongan pada tanggal 18 Juli 2020.

${ }^{6}$ Acep Hermawan, Metodologi Pembelajaran Bahasa Arab (Bandung: PT Remaja Rosdakarya, 2011), 117.

7 Hasil wawancara dengan guru bahasa Arab MA Ma'arif 7 Banjarwati Paciran Lamongan pada tanggal 19 Oktober 2019.
} 
Oleh sebab itu, peneliti memfokuskan penelitian menggunakan media yang berupa Teka Teki Silang dalam pembelajaran bahasa Arab karena perlu adanya suasana yang dapat menumbuhkan semangat siswa yang lebih akan belajar bahasa Arab, khususnya memahami keterampilan imla'. Salah satu cara untuk menciptakan suasana lebih menyenangkan dan lebih nyaman dalam pembelajaran dan pemahaman bahasa Arab adalah dengan bermain, maka dari itu dibutuhkan suatu media yang dapat menggugah semangat dan membuat semua siswa aktif dalam proses belajar mengajar agar keterampilan imla' semakin meningkat. Menurut peneliti, media Teka Teki Silang ini memiliki kelebihan dapat meningkatkan efektifitas dalam pemerolehan kosakata dengan suasana pembelajaran yang lebih menyenangkan dan kompetitif serta lebih simpel untuk diajarkan. Kelebihan lainnya dari media TTS adalah dapat melatih ketelitian atau kejelian siswa dalam menjawab pertanyaan yang mengasah otak dan dapat menemukan penulisan kata-kata bahasa Arab yang terdapat teknik penyambungan antara huruf hijaiyah ketika dimasukkan.

Kata teka teki silang memang tidak asing lagi di telinga kita semua, yang merupakan sebuah permainan yang cara bermainnya dengan mengisi ruang-ruang kosong yang berbentuk kotak dengan huruf-huruf sampai membentuk sebuah kata petunjuk. Teka teki silang akan menjadi media pembelajaran yang mudah dan menyenangkan, diharapkan dapat mempermudah proses pembelajaran dengan mendemonstrasikan terlebih dahulu permainan tersebut.

Dengan menggunakan jenis rancangan Penelitian Tindakan Kelas yang terdiri dari beberapa siklus dan akan dilaksanakan beberapa minggu, diharapkan terdapat peningkatan keterampilan imla' bahasa Arab siswa dengan menggunakan media Teka Teki Silang (TTS). Selain itu, diharapkan siswa dapat lebih aktif dalam hal tulis menulis bahasa Arab, baik dengan menggunakan media TTS atau dalam kesehariannya.

\section{Metode Penelitian}

Jenis penelitian yang dipakai dalam penelitian di MA Ma'arif 7 Banjarwati Paciran Lamongan adalah Penelitian Tindakan Kelas (PTK). Istilah dalam bahasa Inggris adalah Clasroom Action Research (CAR). Dari namanya sudah menunjukkan isi yang terkandung didalamnya, yaitu sebuah kegiatan penelitian yang dilakukan di kelas. ${ }^{8}$

Penelitian Tindakan Kelas (PTK) dapat ditarik kesimpulan bahwa PTK adalah sebuah kegiatan penelitian yang dilakukan oleh guru/calon guru di kelas yang mempunyai tujuan untuk meningkatkan kualitas pembelajaran dengan melakukan perbaikan-perbaikan terhadap sistem pembelajaran. Adapun subjek penelitian ini adalah kelas XI-K IPS MA Ma'arif 7 Banjarwati Paciran Lamongan Tahun Pelajaran 2020/2021.

Dalam penelitian ini, peneliti menggunakan beberapa instrumen untuk mengumpulkan data, diantaranya:

1. Tes

Dalam penelitian ini, peneliti memberikan tes kepada siswa untuk mengukur keterampilan imla' bahasa Arab siswa yang berjumlah 15 siswa pada kelas XI-K IPS MA Ma'arif 7 Banjarwati Paciran Lamongan yang akan dilaksanakan sebanyak 3 kali saat proses pembelajaran pada siklus I, siklus II dan siklus III. Adapun kriteria penilaian dari hasil tes, dapat dilihat dalam tabel di bawah. 
Tabel 1. Kriteria Penilaian

\begin{tabular}{c|c|c|c|c}
\hline Huruf & Angka 0-4 & Angka 0-100 & Angka 0-10 & Predikat \\
\hline A & 4 & $85-100$ & $8,5-10$ & Sangat baik \\
\hline B & 3 & $70-84$ & $7,0-8,4$ & Baik \\
\hline C & 2 & $55-69$ & $5,5-6,9$ & Cukup \\
\hline D & 1 & $40-54$ & $4,0-5,4$ & Kurang \\
\hline E & 0 & $0-39$ & $0,0-0,39$ & Kurang sekali \\
\hline
\end{tabular}

Untuk menghitung hasil tes pada proses pembelajaran media Teka Teki Silang, digunakan rumus mean. Rumusnya sebagai berikut:

$$
M=\sum \frac{X}{N}
$$

Keterangan : $\mathrm{X}=$ Jumlah skor

$$
\mathrm{N}=\text { Jumlah siswa }
$$

2. Observasi

Dalam penelitian ini, peneliti melaksanakan observasi pada setiap siklus yaitu sebanyak dua kali dengan cara mengamati kelas selama proses pembelajaran berlangsung dan juga kemampuan peneliti sebagai pelaksana proses pembelajaran dengan mengundang partisipan sebagai observer.

3. Interview (wawancara)

Dalam penelitian ini, peneliti akan menggunakan bentuk interview terpimpin yang ditujukan kepada siswa kelas XI-K IPS MA Ma'arif 7 Banjarwati tahun pelajaran 2020/2021 tentang tanggapan siswa mengenai media Teka-Teki Silang terhadap peningkatan keterampilan imla' bahasa Arab siswa dan juga kepada Guru Bahasa Arab kelas XI-K IPS MA Ma'arif 7 Banjarwati Paciran Lamongan mengenai peningkatan keterampilan imla' bahasa Arab siswa dengan menggunakan media Teka Teki Silang.

\section{Hasl dan Pembahasan Penelitian}

\section{Pra Tindakan}

Sebelum melakukan penelitian, peneliti mengadakan pra tindakan dengan melakukan wawancara dengan guru bahasa Arab tentang masalah yang dihadapi berkenaan dengan pembelajaran bahasa Arab yang tidak lain yaitu siswa masih kurang aktif dan masih merasa kesulitan dalam belajar bahasa Arab, khususnya dalam hal imla' (keterampilan menulis). Solusi yang dilakukan untuk mengatasi permasalahan yang terjadi dalam kegiatan pembelajaran bahasa Arab diantaranya membuat media yang digunakan dalam pembelajaran yang bersifat menarik dan asyik dimainkan dalam pembelajaran bahasa Arab berlangsung, yakni dengan menggunakan media Teka Teki Silang.

\section{Paparan Data Siklus I}

Pada pelaksanaan tindakan siklus I terbagi dalam empat tahap, yaitu:

a. Perencanaan Tindakan

1) Menentukan pokok bahasan, antara lain dengan menentukan materi.

2) Merencanakan proses pembelajaran yang akan diterapkan dalam kegiatan belajar mengajar yaitu dengan menyusun RPP dan silabus pembelajaran yang sesuai dengan materi yang akan diajarkan.

3) Menyiapkan media pembelajaran dalam penelitian ini yang berupa Teka Teki Silang 
4) Menyiapkan lembar observasi aktivitas belajar siswa dan aktivitas pembelajaran guru serta catatan lapangan untuk melihat bagaimana situasi belajar mengajar ketika media Teka Teki Silang diterapkan.

b. Pelaksanaan Tindakan

1) Pertemuan Pertama

a) Kegiatan Awal (Pendahuluan)

(1) Guru mengucapkan salam sebagai pembuka pertemuan dan menanyakan kabar siswa

(2) Membaca doa sebelum melakukan pembelajaran dan mengecek kehadiran siswa

(3) Guru menyampaikan informasi tentang materi yang akan disampaikan, meliputi : kompetensi dasar dan indikator pencapaian kompetensi

(4) Guru mereview pelajaran yang telah lalu

b) Kegiatan Inti

(1) Guru mendemonstrasikan tentang media Teka Teki Silang yang akan digunakan dalam pembelajaran

(2) Guru memberikan contoh bagaimana cara mengerjakannya atau memainkannya

(3) Guru meminta siswa menulis materi yang dituliskan di papan tulis pada buku tulis masing-masing siswa

c) Kegiatan Akhir (Penutup)

(1) Guru bersama siswa menyimpulkan hasil pelajaran yang telah dibahas

(2) Guru mengadakan refleksi hasil pembelajaran

(3) Guru memberikan motivasi dan mengajak siswa berdoa

(4) Guru mengucapkan salam penutup pembelajaran

2) Pertemuan Kedua

a) Kegiatan Awal (Pendahuluan)

(1) Guru mengucapkan salam sebagai pembuka pertemuan dan menanyakan kabar siswa

(2) Membaca doa sebelum melakukan pembelajaran dan mengecek kehadiran siswa

(3) Guru menyampaikan informasi tentang materi yang akan disampaikan, meliputi : kompetensi dasar dan indikator pencapaian kompetensi

(4) Guru mereview pelajaran yang telah lalu

b) Kegiatan Inti

(1) Guru memberikan lembaran kertas kepada setiap siswa dan meminta siswa untuk menjawab soal Teka Teki Silang tersebut

(2) Guru menentukan batas waktu dan memberikan kesempatan siswa menanyakan mufradat yang belum diketahui artinya

(3) Guru memberikan kesempatan perwakilan siswa maju ke depan menulis jawabannya di papan dan memberikan reward kepada mereka

(4) Guru membahas jawaban Teka Teki Silang bersama siswa

c) Kegiatan Akhir (Penutup)

(1) Guru bersama siswa menyimpulkan hasil pelajaran yang telah dibahas

(2) Guru mengadakan refleksi hasil pembelajaran

(3) Guru memberikan motivasi dan mengajak siswa berdoa

(4) Guru mengucapkan salam penutup pembelajaran 
c. Observasi atau Pengamatan

Berikut data pengamatan keterampilan imla' bahasa Arab siswa pada siklus I disajikan pada tabel sebagai berikut:

Tabel Pengamatan Keterampilan Imla' Siklus I

\begin{tabular}{c|l|c}
\hline No & \multicolumn{1}{|c|}{ Keterampilan imla' } & Siklus I \\
\hline 1 & Jumlah Peserta & 15 \\
\hline 2 & Nilai Rata-rata & 74 \\
\hline 3 & Siswa Tuntas & 9 \\
\hline 4 & Siswa Tidak Tuntas & 6 \\
\hline 5 & Ketuntasan & $60 \%$ \\
\hline
\end{tabular}

Berdasarkan tabel diatas, dapat diketahui bahwa keterampilan imla' bahasa Arab siswa masih kurang. Hal ini dapat dilihat dari prosentase yang mencapai $60 \%$ yang mencapai Kriteria Ketuntasan Minimal (KKM) dan siswa dengan prosentase $40 \%$ yang belum mencapai Kriteria Ketuntasan Minimal (KKM). Dengan ini siswa dikategorikan Cukup.

Pada akhir siklus I diberikan tes untuk mengetahui peningkatan keterampilan imla' bahasa Arab siswa dengan menggunakan media Teka Teki Silang. Adapun hasil tes pada siklus I disajikan pada tabel sebagai berikut:

Tabel Hasil Tes Siswa Siklus I

\begin{tabular}{c|l|c}
\hline No & \multicolumn{1}{|c|}{ Hasil Tes } & Siklus I \\
\hline 1 & Jumlah Peserta & 15 \\
\hline 2 & Nilai Rata-rata & 77,33 \\
\hline 3 & Siswa Tuntas & 10 \\
\hline 4 & Siswa Tidak Tuntas & 5 \\
\hline 5 & Ketuntasan & $67 \%$ \\
\hline
\end{tabular}

Berdasarkan tabel diatas dapat diketahui bahwa peningkatan keterampilan imla' bahasa Arab siswakelas XI-K MA Ma'arif 7 Banjarwati Paciran Lamongan dengan menggunakan media Teka Teki Silang masih belum maksimal. Hal ini dapat dilihat dari 10 siswa dengan prosentase 67\% yang telah mencapai Kriteria Ketuntasan Minimal (KKM) dan 5 siswa dengan prosentase 33\% yang belum mencapai Kriteria Ketuntasan Minimal (KKM). Dengan ini siswa dikategorikan Cukup.

d. Refleksi

Peneliti akan memberikan tindakan perbaikan karena masih ada siswa yang nilainya dibawah KKM, maka ada tindakan perbaikan pada siklus II. Tindakan perbaikan tersebut perlu dilakukan agar mendapatkan peningkatan lebih baik lagi dalam keterampilan imla' bahasa Arab yang sesuai dengan KKM atau bahkan jauh diatas KKM yakni 75.

\section{Paparan Data Siklus II}

Pada pelaksanaan tindakan siklus II terbagi dalam empat tahap, yaitu:

a. Perencanaan Tindakan

1) Menentukan pokok bahasan, antara lain dengan menentukan materi.

2) Merencanakan proses pembelajaran yang akan diterapkan dalam kegiatan belajar mengajar yaitu dengan menyusun RPP dan silabus pembelajaran yang sesuai dengan materi yang akan diajarkan.

3) Menyiapkan media pembelajaran dalam penelitian ini yang berupa Teka Teki Silang.

4) Menyiapkan lembar observasi aktivitas belajar siswa dan aktivitas pembelajaran guru 
serta catatan lapangan untuk melihat bagaimana situasi belajar mengajar ketika media

Teka Teki Silang diterapkan.

b. Pelaksanaan Tindakan

1) Pertemuan Pertama

a) Kegiatan Awal (Pendahuluan)

(1) Guru mengucapkan salam sebagai pembuka pertemuan dan menanyakan kabar siswa.

(2) Membaca doa sebelum melakukan pembelajaran dan mengecek kehadiran siswa

(3) Guru menyampaikan informasi tentang materi yang akan disampaikan, meliputi : kompetensi dasar dan indikator pencapaian kompetensi

(4) Guru mereview pelajaran yang telah lalu.

b) Kegiatan Inti

(1) Guru mendemonstrasikan tentang media Teka Teki Silang yang akan digunakan dalam pembelajaran

(2) Guru memberikan contoh bagaimana cara mengerjakannya atau memainkannya

(3) Guru meminta siswa menulis materi yang dituliskan di papan tulis pada buku tulis masing-masing siswa

c) Kegiatan Akhir (Penutup)

(1) Guru bersama siswa menyimpulkan hasil pelajaran yang telah dibahas

(2) Guru mengadakan refleksi hasil pembelajaran

(3) Guru memberikan motivasi dan mengajak siswa berdoa Guru mengucapkan salam penutup pembelajaran

2) Pertemuan Kedua

a) Kegiatan Awal (Pendahuluan)

(1) Guru mengucapkan salam sebagai pembuka pertemuan dan menanyakan kabar siswa

(2) Membaca doa sebelum melakukan pembelajaran dan mengecek kehadiran siswa

(3) Guru menyampaikan informasi tentang materi yang akan disampaikan, meliputi : kompetensi dasar dan indikator pencapaian kompetensi

(4) Guru mereview pelajaran yang telah lalu

b) Kegiatan Inti

(1) Guru memberikan lembaran kertas kepada setiap siswa dan meminta siswa untuk menjawab soal Teka Teki Silang tersebut

(2) Guru menentukan batas waktu dan memberikan kesempatan siswa menanyakan mufradat yang belum diketahui artinya

(3) Guru memberikan kesempatan perwakilan siswa maju ke depan menulis jawabannya di papan dan memberikan reward kepada mereka

(4) Guru membahas jawaban Teka Teki Silang bersama siswa

c) Kegiatan Akhir (Penutup)

(1) Guru bersama siswa menyimpulkan hasil pelajaran yang telah dibahas

(2) Guru mengadakan refleksi hasil pembelajaran

(3) Guru memberikan motivasi dan mengajak siswa berdoa

(4) Guru mengucapkan salam penutup pembelajaran 
c. Observasi atau Pengamatan

Berikut data pengamatan keterampilan imla' bahasa Arab siswa pada siklus II disajikan pada tabel sebagai berikut:

Tabel Pengamatan Keterampilan Imla' Siklus II

\begin{tabular}{c|c|c}
\hline No & Keterampilan imla' & Siklus II \\
\hline 1 & Jumlah Peserta & 15 \\
\hline 2 & Nilai Rata-rata & 83,67 \\
\hline 3 & Siswa Tuntas & 11 \\
\hline 4 & Siswa Tidak Tuntas & 4 \\
\hline 5 & Ketuntasan & $73 \%$ \\
\hline
\end{tabular}

Berdasarkan tabel diatas, dapat diketahui bahwa keterampilan imla' bahasa Arab siswa sudah baik. Hal ini dapat dilihat dari sebanyak 11 siswa dengan prosentase $73 \%$ yang mencapai Kriteria Ketuntasan Minimal (KKM) dan 4 siswa dengan prosentase $27 \%$ yang belum mencapai Kriteria Ketuntasan Minimal (KKM). Dengan ini siswa dikategorikan Baik.

Pada akhir siklus II diberikan tes untuk mengetahui peningkatan keterampilan imla' bahasa Arab siswa dengan menggunakan media Teka Teki Silang. Adapun hasil tes pada siklus II disajikan pada tabel sebagai berikut:

Tabel Hasil Tes Siswa Siklus II

\begin{tabular}{c|l|c}
\hline No & \multicolumn{1}{|c|}{ Hasil Tes } & Siklus II \\
\hline 1 & Jumlah Peserta & 15 \\
\hline 2 & Nilai Rata-rata & 83,67 \\
\hline 3 & Siswa Tuntas & 11 \\
\hline 4 & Siswa Tidak Tuntas & 4 \\
\hline 5 & Ketuntasan & $73 \%$ \\
\hline
\end{tabular}

Berdasarkan tabel diatas dapat diketahui bahwa peningkatan keterampilan imla' bahasa Arab siswakelas XI-K MA Ma'arif 7 Banjarwati Paciran Lamongan dengan menggunakan media Teka Teki Silang sudah baik. Hal ini dapat dilihat dari sebanyak 11 siswa dengan prosentase $73 \%$ yang telah mencapai Kriteria Ketuntasan Minimal (KKM) dan 4 siswa dengan prosentase 27\% yang belum mencapaiKriteria Ketuntasan Minimal (KKM). Dengan ini siswa dikategorikan Baik.

d. Refleksi

Peneliti akan memberikan tindakan perbaikan karena masih ada siswa yang nilainya di bawah KKM, maka ada perbaikan pada siklus III. Tindakan perbaikan tersebut perlu dilakukan agar mendapatkan peningkatan lebih baik lagi dalam keterampilan imla bahasa Arab yang sesuai dengan KKM atau bahkan jauh di atas KKM yakni 75.

\section{Paparan Data Siklus III}

Pada pelaksanaan tindakan siklus III terbagi dalam empat tahap, yaitu:

a. Perencanaan Tindakan

1) Menentukan pokok bahasan, antara lain dengan menentukan materi.

2) Merencanakan proses pembelajaran yang akan diterapkan dalam kegiatan belajar mengajar yaitu dengan menyusun RPP dan silabus pembelajaran yang sesuai dengan materi yang akan diajarkan

3) Menyiapkan media pembelajaran dalam penelitian ini yang berupa Teka Teki Silang. 
4) Menyiapkan lembar observasi aktivitas belajar siswa dan aktivitas pembelajaran guru serta catatan lapangan untuk melihat bagaimana situasi belajar mengajar ketika media Teka Teki Silang diterapkan.

b. Pelaksanaan Tindakan

1) Pertemuan Pertama

a) Kegiatan Awal

(1) Guru mengucapkan salam sebagai pembuka pertemuan dan menanyakan kabar siswa

(2) Membaca doa sebelum melakukan pembelajaran dan mengecek kehadiran siswa

(3) Guru menyampaikan informasi tentang materi yang akan disampaikan, meliputi : kompetensi dasar dan indikator pencapaian kompetensi

(4) Guru mereview pelajaran yang telah lalu

b) Kegiatan Inti

(1) Guru mendemonstrasikan tentang media Teka Teki Silang yang akan digunakan dalam pembelajaran

(2) Guru memberikan contoh bagaimana cara mengerjakannya atau memainkannya

(3) Guru meminta siswa menulis materi yang dituliskan di papan tulis pada buku tulis masing-masing siswa

c) Kegiatan Akhir (Penutup)

(1) Guru bersama siswa menyimpulkan hasil pelajaran yang telah dibahas

(2) Guru mengadakan refleksi hasil pembelajaran

(3) Guru memberikan motivasi dan mengajak siswa berdoa

(4) Guru mengucapkan salam penutup pembelajaran

2) Pertemuan Kedua

a) Kegiatan Awal (Pendahuluan)

(1) Guru mengucapkan salam sebagai pembuka pertemuan dan menanyakan kabar siswa

(2) Membaca doa sebelum melakukan pembelajaran dan mengecek kehadiran siswa

(3) Guru menyampaikan informasi tentang materi yang akan disampaikan, meliputi : kompetensi dasar dan indikator pencapaian kompetensi

(4) Guru mereview pelajaran yang telah lalu

b) Kegiatan Inti

(1) Guru memberikan lembaran kertas kepada setiap siswa dan meminta siswa untuk menjawab soal Teka Teki Silang tersebut

(2) Guru menentukan batas waktu dan memberikan kesempatan siswa menanyakan mufradat yang belum diketahui artinya

(3) Guru memberikan kesempatan perwakilan siswa maju ke depan menulis jawabannya di papan dan memberikan reward kepada mereka

(4) Guru membahas jawaban Teka Teki Silang bersama siswa

c) Kegiatan Akhir (Penutup)

(1) Guru bersama siswa menyimpulkan hasil pelajaran yang telah dibahas

(2) Guru mengadakan refleksi hasil pembelajaran

(3) Guru memberikan motivasi dan mengajak siswa berdoa 
(4) Guru mengucapkan salam penutup pembelajaran

c. Observasi atau Pengamatan

Berikut data pengamatan keterampilan imla' bahasa Arab siswa pada siklus III disajikan pada tabel sebagai berikut:

Tabel Pengamatan Keterampilan Imla' Siklus III

\begin{tabular}{c|l|c}
\hline No & \multicolumn{1}{|c|}{ Keterampilan imla' } & Siklus III \\
\hline 1 & Jumlah Peserta & 15 \\
\hline 2 & Nilai Rata-rata & 89 \\
\hline 3 & Siswa Tuntas & 14 \\
\hline 4 & Siswa Tidak Tuntas & 1 \\
\hline 5 & Ketuntasan & $93 \%$ \\
\hline
\end{tabular}

Berdasarkan tabel diatas, dapat diketahui bahwa keterampilan imla' bahasa Arab siswa sudah sangat baik. Hal ini dapat dilihat dari sebanyak 14 siswa dengan prosentase 93\% yang mencapai Kriteria Ketuntasan Minimal (KKM) dan hanya 1 siswa dengan prosentase 7\% yang belum mencapaiKriteria Ketuntasan Minimal (KKM). Dengan ini siswa dikategorikan Sangat Baik.

Pada akhir siklus II diberikan tes untuk mengetahui peningkatan keterampilan imla' bahasa Arab siswa dengan menggunakan media Teka Teki Silang. Adapun hasil tes pada siklus III disajikan pada tabel sebagai berikut:

Tabel Hasil Tes Siswa Siklus III

\begin{tabular}{c|l|c}
\hline No & \multicolumn{1}{|c|}{ Hasil Tes } & Siklus III \\
\hline 1 & Jumlah Peserta & 15 \\
\hline 2 & Nilai Rata-rata & 88 \\
\hline 3 & Siswa Tuntas & 14 \\
\hline 4 & Siswa Tidak Tuntas & 1 \\
\hline 5 & Ketuntasan & $93 \%$ \\
\hline
\end{tabular}

Berdasarkan tabel diatas dapat diketahui bahwa peningkatan keterampilan imla' bahasa Arab siswakelas XI-K MA Ma'arif 7 Banjarwati Paciran Lamongan dengan menggunakan media Teka Teki Silang sudah baik. Hal ini dapat dilihat dari sebanyak 14 siswa dengan prosentase $93 \%$ dan hanya 1 siswa yang masih berada dibawah KKM. Dengan ini siswa dikategorikan Sangat Baik.

d. Refleksi

Melihat situasi dan kondisi siswa yang sudah baik dalam peningkatan keterampilan imla' bahasa Arab, maka tidak perlu dilanjutkan pada siklus berikutnya.

\section{Paparan Data Lengkap}

Penelitian ini dilaksanakan di MA Ma'arif 7 Banjarwati Paciran Lamongan yaitu pada kelas XI IPS yang berjumlah 15 anak. Penelitian ini dilakukan sebanyak 3 siklus, yaitu siklus I dilaksanakan dengan dua kali pertemuan yaitu pada tanggal 26 Juli dan 02 Agustus 2020, siklus 
II dilaksanakan dengan dua kali pertemuan yaitu pada tanggal 09 dan 16 Agustus 2020 dan siklus III dilaksanakan dengan dua kali pertemuan yaitu pada tanggal 23 dan 30 Agustus 2020. Namun sebelum melaksanakan kegiatan siklus penelitian, peneliti mengadakan pra tindakan dengan melakukan wawancara dengan guru bahasa Arab tentang masalah yang dihadapi berkenaan dengan pembelajaran bahasa Arab yang tidak lain yaitu siswa masih kurang aktif dan masih merasa kesulitan dalam belajar bahasa Arab, khususnya dalam hal imla' (keterampilan menulis).

Selanjutnya untuk mengetahui tingkat keterampilan imla' siswa, maka peneliti melakukan pengamatan keterampilan imla' bahasa Arab siswa. Peningkatan yang terjadi pada keterampilan imla' bahasa Arab pada siswa kelas XI-K IPS MA Ma'arif 7 Banjarwati Paciran Lamongan setiap siklusnya dapat dilihat pada tabel sebagai berikut.

Tabel Peningkatan Pengamatan Keterampilan Imla'

\begin{tabular}{c|l|c|c|c}
\hline No & Keterampilan imla' & Siklus I & Siklus II & Siklus III \\
\hline 1 & Jumlah Peserta & 15 & 15 & 15 \\
\hline 2 & Nilai Rata-rata & 74 & 83,67 & 89 \\
\hline 3 & Siswa Tuntas & 9 & 11 & 14 \\
\hline 4 & Siswa Tidak Tuntas & 6 & 4 & 1 \\
\hline 5 & Ketuntasan & $60 \%$ & $73 \%$ & $93 \%$ \\
\hline
\end{tabular}

Dari hasil pengamatan keterampilan imla' bahasa Arab diatas menunjukkan bahwa keterampilan imla' siswa mengalami peningkatan yaitu dari siklus I 60\% ke siklus II 73\% ke siklus III 93\%.

Selanjutnya untuk mengetahui peningkatan keterampilan imla' siswa dengan penerapan media Teka Teki Silang, maka peneliti melakukan tes yang peningkatan hasil setiap siklusnya dapat dilihat pada tabel sebagai berikut:

Tabel Peningkatan Hasil Tes Siswa

\begin{tabular}{c|l|c|c|c}
\hline No & \multicolumn{1}{|c|}{ Hasil Tes } & Siklus I & Siklus I & Siklus II \\
\hline 1 & Jumlah Peserta & 15 & 15 & 15 \\
\hline 2 & Nilai Rata-rata & 77,33 & 83,67 & 88 \\
\hline 3 & Siswa Tuntas & 10 & 11 & 14 \\
\hline 4 & Siswa Tidak Tuntas & 5 & 4 & 1 \\
\hline 5 & Ketuntasan & $67 \%$ & $73 \%$ & $93 \%$ \\
\hline
\end{tabular}

Dari hasil tes diatas menunjukkan bahwa keterampilan imla' bahasa Arab siswa dengan penerapan media Teka Teki Silang mengalami peningkatan yaitu dari siklus I 67\% ke siklus II $73 \%$ ke siklus III 93\%.

Setelah melaksanakan kegiatan siklus penelitian, peneliti melakukan wawancara dengan siswa kelas XI-K IPS MA Ma'arif 7 Banjarwati Paciran Lamongan tentang penerapan media Teka Teki Silang dalam meningkatkan keterampilan imla' bahasa Arab yang tidak lain menyatakan bahwa media Teka Teki Silang sangat disukai karena lebih bisa membuat siswa memahami materi bahasa Arab dan nilai yang diperoleh pun lebih meningkat daripada sebelumnya meskipun kesulitan yang dialami yaitu mufradat yang belum banyak dimiliki. 


\section{Kesimpulan}

Penerapan media Teka Teki Silang (TTS) dalam meningkatkan keterampilan imla' bahasa Arab pada siswa kelas XI-K IPS MA Ma'arif 7 Banjarwati Paciran Lamongan Tahun Pelajaran 2020/2021dilaksanakan sebagai berikut : Pertama, Mendemonstrasikan telebih dahulu media Teka Teki Silang kemudian memberikan contoh cara mengerjakannya atau memainkannya. Kedua, meminta siswa menulis materi di buku tulis masing-masing siswa untuk mengetahui kemampuan imla' bahasa Arab siswa. Ketiga, memberikan lembaran kertas dan meminta siswa untuk menjawab soal Teka Teki Silang. Keempat, Menentukan batas waktu pengerjaan dan memberikan kesempatan untuk menanyakan mufrodat yang belum diketahui artinya serta memberikan kesempatan perwakilan siswa maju kedepan menulis jawaban di papan tulis.

Peningkatan keterampilan imla' bahasa Arab dengan penerapan media Teka Teki Silang (TTS) pada siswa kelas XI-K IPS MA Ma'arif 7 Banjarwati Paciran Lamongan tahun pelajaran 2020/2021 dapat diketahui dari ketuntasan selama proses pembelajaran berlangsung, dimana ketuntasan belajar pada siklus I diperoleh rata-rat nilai $67 \%$, dan pada siklus II diperoleh rata-rata nilai $73 \%$ dan pada siklus III diperoleh rata-rat nilai 93\%.

\section{Daftar Rujukan}

Ainin, Mohammad, Metodologi Penelitian Bahasa Arab, Malang: CV. Bintang Sejahtera, 2016. Arikunto, Suharismi, Prosedur Penelitian Suatu Pendekatan Praktik, Jakarta: PT. RinekaCipta, 2013. Asrori, Imam, Evaluasi Pembelajaran Bahasa Arab, Malang: Miskyat, 2012.

Hermawan, Acep, Metodologi Pembelajaran Bahasa Arab, Bandung: PT Remaja Rosdakarya, 2011. Nuha, Ulin, Metodologi Super Efektif Pembelajaran BahasaArab, Yogyakarta: Diva Press, 2012. Nuha, Ulin, Ragam Metodologi \& Media Pembelajaran Bahasa Arab, Yogyakarta: Diva Pres, 2016. Rosyidi, Abdul Wahab dan Mamlu'atul Ni'mah, Memahami Konsep Dasar Pembelajaran Bahasa Arab, Malang: UIN Maliki Press, 2012.

Sugiyono, Metodologi Penelitian Kuantitatif Kualitatif dan R\&D, Bandung: Alfabeta, 2011.

Suprijono, Agus, Cooperative Learning, Surabaya: Pustaka Fajar, 2011. 